\title{
Provisioning and Cultural Services of Restored Ecosystem in Mount Kelud after 2014 Eruption
}

\author{
Ardina Tanjungsari ${ }^{1}$, Luchman Hakim², Catur Retnaningdyah ${ }^{2}$ \\ ${ }^{1}$ Master Program of Biology, Faculty of Mathematics and Natural Sciences, Brawijaya University, Malang, Indonesia \\ ${ }^{2}$ Department of Biology, Faculty of Mathematics and Natural Sciences, Brawijaya University, Malang, Indonesia
}

\begin{abstract}
Mount Kelud eruption in 2014 was recorded as the largest eruption in the history of Mount Kelud volcanic activity. The ecosystem restoration was implemented after the eruption. However, few studies regarding the value of the restored area, mainly focus on the perspective of ecosystem services values. The objectives of this study were to evaluate the ecosystem services of restored area of Mt. Kelud after three years or eruption restoration program and develop appropriate restoration strategies based on the potentiality of its cultural services. A field survey was done at the restored area after mountain eruption in 2014. The location of Mt. Kelud is administratively located at Sugihwaras Village, Ngancar District, Kediri Regency, East Java. Ecosystem service was observed following Wunder and Thorsen ecosystem service classification. Interviews with key sources were performed to generate data regarding the socioecological aspect of restoration program and determines the ecosystem services in the perspectives of the local community. In order to describe the strategy for the development of nature-based tourism as one of the important cultural services in Mt. Kelud, a SWOT analysis was performed to evaluate the possible strategy to developed naturebased tourism in the restored area. Results of this study showed that two ecosystem services, the provisioning and cultural services, were identified to contribute to the local community. Their contributions demonstrated through numerous forestry program and nature-based tourism activity. The potentiality of nature-based tourism development in the restored area depended on the ability to drawn restoration planning which was combined with sustainable recreation activity in the restoration area.
\end{abstract}

Keywords: Ecosystem services, Mountain Kelud, Mountain restoration, Mountain tourism

\section{INTRODUCTION}

Mt. Kelud is one of the active volcanoes in East Java. Ecologically, Mt. Kelud provides a significant role in environmental aspect, ranging from water resources regulation, climate regulation and home to numerous biodiversity which is important to support human life surrounding mountain area. Mt. Kelud is one of the active mountains on Java Island. Socioculturally, Mt. Kelud is important sites for Javanese. As many mountain areas in Java, Mt. Kelud has been considered as one of the mountains with spiritual value. These lead Mt. Kelud is one of the religious tourism destination $[1,2,3]$.

Volcanology and Geological Hazard Mitigation Center records frequent activity of the mountain and reports that the last eruption on February 13, 2014 is one of the biggest eruption in history of Mt. Kelud eruptions. This eruption

Correspondence address:

Ardina Tanjungsari

Email : ardinatanjungsari@gmail.com

Address : Master Program of Biology, Faculty of Mathemathics and Natural Sciences, Brawijaya University, Malang has a wide impact from economic, cultural or social values, and ecosystem services. Effort to repair mountain degradation after eruption has been done for numerous purposes. Restoration programs has been implemented after eruption, with the objective is recovering and developing native vegetation of $\mathrm{Mt}$. Kelud after eruption. Socio-ecologically, it is also important to reduce natural hazard which are resulted from abandoned lands after mountain eruption. The first restoration was performed by Perum Perhutani and Unity Stakeholder Forest Kediri conservation program after the eruption of the volcano in February 2014 in cooperation with the Kediri regency. Degraded mountain restoration is one of the important programs in many regency in Java, especially region which are located at the mountainous area $[4,5]$.

Mt. Kelud, Kediri Regency, East Java, a strato-shaped mountain, is one the famous nature-based tourism recreation area. Mountaineering, sun rise and sun set seeing are the favorite's tourism program in Mt. Kelud. Statistical data shows that the number of tourist in Mt. Kelud area increase significantly. In order to increase tourist satisfaction, the local 
government of Kediri has been established tourist facility in Mt. Kelud. Recently, the accessibility of Mt. Kelud easier than before, and this situation lead to the increasing tourism activity in Mt. Kelud [6].

After four years of restoration program, however, less ecological services of the restored area has been implemented. Basically, the success of Mt. Kelud restoration is very important in the sustainability of tourism in the natural environment. The concept of ecosystem services theoretically was brought into common use by the Millennium Ecosystem Assessment (MA), a global initiative established in 1999 to assess how ecosystem change would influence human well-being [7]. The MA divided these services into four categories, they are supporting services, provisioning services, regulating services, and cultural services [8].

The aims of the research were to describe the ecosystem services provided by Mt. Kelud after four years of the restoration program.

\section{MATERIAL AND METHOD Study Site}

The location of Mt. Kelud is administratively located in the district of Kediri, Blitar Regency and Malang Regency in East Java Province. The altitude of the observed area ranges from $\pm 1097 \mathrm{~m}$ asl to $1200 \mathrm{~m}$ asl. Interviews related to the environmental services of the ecosystem was conducted at Sugihwaras Village, in which the local community in the villages interacts with the restored area. Geographically it is located on $112^{\circ} 29^{\prime} 35,9$ BT and $7^{\circ} 93^{\prime} 26,3$ LS (Fig. 1) in Ngancar District, Kediri Regency, East Java. The restoration area is located close to the forest Modangan and \pm 500 $\mathrm{m}$ distance from the crater of $\mathrm{Mt}$. Kelud until pathway corridor tour to Mount Kelud.

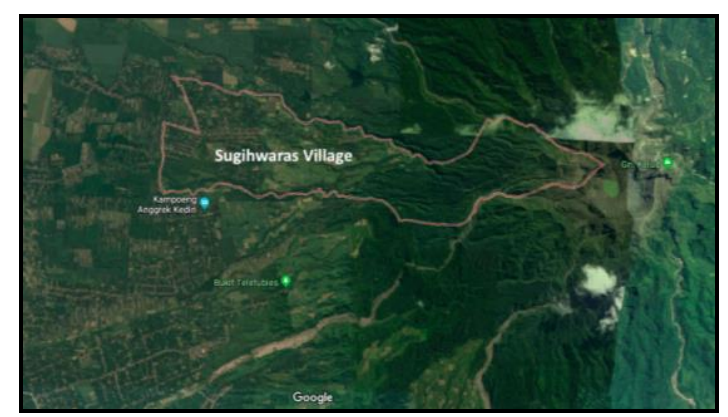

Figure 1.Research location in Sugihwaras Village, Ngancar District, Kediri Regency, East Java.

\section{Data Collection}

Field observation was done in the restored area in Sugihwaras village. The observation was done through direct observation regarding the category of ecosystem services. Semi-structured interviews consist of several key questions that asked to define the areas to be explored. A total of 13 informants were interviewed to determine the ecosystems services of restored area of Mt. Kelud. Informants in this study consist of an informal leader, regency staff of Kediri Regency, representative of PERHUTANI (Indonesian Forest Enterprises) and local farmers. The questions were asked to key sources. Descriptive analysis was performed to generate the comprehensive fact about the restoration and tourism aspect of Mt. Kelud.

\section{RESULT AND DISCUSSION \\ Description of Recent Restored Area}

The restoration site administratively was located at the upper zone of Sugihwaras Village. In the perspectives of area management, the restored area is an integral park of mountain forest of Mt. Kelud under the management of PERHUTANI. Thus, PERHUTANI as one of the state-owned enterprises has a responsibility to keep and maintain the forest. In fact, several limitations in forest management facing fundamental problems, they were including number and capacity staff. These lead to a strategy to involve surrounding community forest as a group in forest management, with sharing benefits scenarios in the implementation [9].

After three years of restoration program in the degraded area, Mt. Kelud become greenish when seen from distance. There were various plant species has been found in restored area, they were stake plants including Calliandra calothyrsus (Red Kaliandra), Caliandra tetragona (White Kaliandra), Clidemia hirta (Harendongbulu), Macaranga hispida (Mahang), and Trema orientalis (Anggrung). In addition, there are herbaceous plants such as Homalanthus sp. (Tutup), Anaphalis longifolia (Edelweiss), Imperata cylindrical (Alang-alang) and Eupatorium inulifolium (Krinyuh). These plants provide regulatory services as producers in food webs or climate settings through carbon sequestration. Several species, however, is invasive species (i.e. Eupatorium inulifolium) which are able to minimize to opportunities of native plant ecosystem to build new population after degraded. The species of Trema orientalis 
and Homalanthus sp. are the native species to the mountain area in Java [10].

The restored area has been used by human for several purposes, ranging from activity to meet daily life (i.e. collecting resources for food and farming) to the optimizing services aspect potentiality of restored sites (i.e. tourism). The numerous human activity shows that humans have interested in the ecosystem's resources in the restored area, and therefore it is important to increase the ecosystem services of the area to support human prosperity. The situation in Mt. Kelud basically similar to another forest that was resources usage by the local community. In such a case, the challenges for the forest resources management, including restoration programs, is involving community into forest conservation programs and establishing many economic and social opportunities which are able to attract local community involved in the program $[11,12]$.

\section{Types of Ecosystem Services on Restored Site}

From four aspect of ecosystem services, namely regulating, provisioning, supporting and culture [5], provisioning service and cultural services have been observed in restoration sites in Mt. Kelud. There is the potentiality of supporting and regulating, but to determine such ecosystem services many filed evidence was needed. Identifying ecosystem services of a particular area, including restored area, is important to determine the potential public support in the restoration area. Sites with the ability to contribute to the human life often appreciated, and support can be generated from publication [13]. In the restored area in Mt. Kelud, two observed environmental serves; the provisioning and cultural services were observed, and such ecosystem services can be described below:

\section{Provisioning Services}

The restored area of Mt. Kelud successfully provides provisioning service to the community who lives in surrounding restored area. The provisioning services officially facilitated by PERHUTANI program called PHBM (community forest-based management). These programs allow community in forest farmer called LMDH (Lembaga Masyarakat Desa Hutan). Through the collaboration, local people surrounding Mt.Kelud which area member of LMDH has access to use lands in PERHUTANI to cultivate some crops species under tree stands, or in a degraded area with farmer's obligation to plant and maintain some tree species recommended by PERHUTANI [14].

A local community who are joint in $\mathrm{LMDH}$ can use the restored to cultivate some vegetables following the strict conditions. The annual plant tree which is planted in restored are included Hevea brasiliensis (rubber), Albizia chinensis (Sengon), Durio zibethinus (Durian), Carica papaya (papaya), Persea americana (Avocado), Musa paradisiaca (Banana). Basically, these plants are considered as multi purposes tree species (MPTS) which were planted to serve both ecosystem functions and economical benefits for the local community. Many species basically has economic value and planted as part of the farmer's strategy to increase the household's income. With this schemes, it is wished local community support the resortion programs in the degraded area [15].

The climates of Mt. Kelud provides opportunities for the development of plantation area and horticulture. This study records that plantations in the area around the peak of the mountain included are Coffea canephora (coffee), Hevea brasiliensis (rubber tree), Saccharum officinarum (sugar cane), Syzygium aromaticum (cloves), and Albizia chinensis (sengon). In addition, many planted fruit crops, such as Ananas comosus (pineapple), Durio zibethinus (durian), Hylocereus polyrhizus (red dragon fruit), Carica papaya (papaya), and others are widely grown by local companies and communities. Mountains often provide fertile soils and suitable climates for cultivated numerous plants [16].

Ecosystem restoration on a landscape scale, aside from the sustainable management of other land use types including pasturelands, agriculture, forestry, and the expansion and consolidation of protected areas, is increasingly recognized as important activities for biodiversity conservation [17].

\section{Cultural Services}

The restored area recently plays an important role in the cultural aspect. This study found two aspects of the cultural landscape, namely recreation used through nature-based tourism, and spiritual enrichment. These can be described below:

1. Tourism and Aesthetic Values

Mt. Kelud provides spectacular landscapes for sightseeing and mountain trekking for adventure activity. According to informant, 
mountain tourism recently grows significantly and it is basically provides economic development opportunities for many villages surrounding Mt. Kelud, especially area which area related to tourism activity. Before last eruption in February 2014, the main attraction of Mt. Kelud is the lake in the crater of mountain. The lake disappears after eruption and small peak occurs after eruption. Other important attraction in Mt. Kelud are including park of $\mathrm{Mt}$. Kelud and hot springs. Numerous tourist programs has been proposed, including rock climbing, walks to Gajah Mungkur hills, hot spring bathing, souvenir shopping center, outbound, and theater. However, the growth of tourism in Mt. Kelud decrease after Mt. Kelud eruptions, the tourist destination has increased the number of visits during weekends, national holidays and school holidays, which averaged 1,000 people per day, compared to normal days which average only 250 people per day [18].
2. Spiritual Enrichment

One of the spiritual activities which are the cultural services of Mount Kelud is the larung sesaji. Larungsesaji is an annual agenda that is carried out by villagers located around the slopes of Mt.Kelud. This activity is a form of local wisdom that reflects on one of the legends that are about beautiful princess Kediri, named Dewi Kilisuci and Lembu Suro. Local people surrounding Mt. Kelud shows high respect to the traditional legend and in some situation related to Mt. Kelud uses the legends as one of the social norms. Specific events have been done by local people, especially in Muharom month in Islamic calendar system, or often called Suro in Javanese calendar. The aim of larung sesaji are asking to God for the public salvation of Sugihwaras and surrounding villages were given salvation, then asking for blessings for the farming community to be given a satisfactory agricultural production [19].

Table 1. Tourism Development Strategy in the restored area in Mt. Keludbased on SWOT Analysis

\begin{tabular}{|c|c|}
\hline Internal factors & $\begin{array}{l}\text { Strengths }(\mathrm{S}) \\
\text { 1. Strategic geographic location } \\
\text { 2. The increase of media promotion and } \\
\text { communication } \\
\text { 3. Local government policy on tourism } \\
\text { development in the natural area }\end{array}$ \\
\hline \multicolumn{2}{|l|}{ Opportunities (O) } \\
\hline $\begin{array}{l}\text { 1. The increase of } \\
\text { mountain-based } \\
\text { popularity }\end{array}$ & \multirow{2}{*}{$\begin{array}{l}\text { 1. Providing standard tourism facility in a } \\
\text { sustainable manner. It can be involved in } \\
\text { planning the design of the mountain as a } \\
\text { tourism destination. The carrying capacity } \\
\text { of mountain visitation should be } \\
\text { developed as an environmental } \\
\text { instrument in achieving sustainable } \\
\text { tourism destination. } \\
\text { 2. Socializing regional policy in tourism } \\
\text { development intensively to community } \\
\text { and stakeholders with the objectives is } \\
\text { generating public support for restoration } \\
\text { program and mountain tourism } \\
\text { development }\end{array}$} \\
\hline $\begin{array}{l}\text { 2. The increase of } \\
\text { conservation agency in } \\
\text { the restoration program }\end{array}$ & \\
\hline \multicolumn{2}{|l|}{ Threats $(T)$} \\
\hline $\begin{array}{l}\text { 1. Increase travel interest } \\
\text { to natural } \\
\text { environment leads to } \\
\text { mass tourism }\end{array}$ & $\begin{array}{l}\text { Establishing roles and code of conduct for } \\
\text { tourist who will visit Mt. Kelud } \\
\text { 2. Strengthening local community and } \\
\text { management to implement sustainable }\end{array}$ \\
\hline $\begin{array}{l}\text { 2. Competition with } \\
\text { other nature-based } \\
\text { tourism }\end{array}$ & $\begin{array}{l}\text { tourism principles, and strengthening the } \\
\text { ability of local community and } \\
\text { management to provides numerous } \\
\text { tourism product which area meets } \\
\text { ecotourism principles }\end{array}$ \\
\hline
\end{tabular}

Weaknesses (W)

1. Poor understanding and support of the local community, especially in the restoration program

2. Poor of technical approach in the restoration program

1. Promoting human resources development to implement restoration and tourism development program.

2. Promoting restoration program in Mt. Kelud as important environmental programs which are able to succeed with the support of tourism

1. Providing comprehensive planning to optimize tourism potential, while at the same time promoting restoration programs as part of the design of tourism product in Mt. Kelud 


\section{Enhancing Cultural Services of in Restoration Sites in Mt. Kelud}

There were possibilities and opportunities to strengthen and support the cultural services of the restored area to the public. In such a case, nature-based tourism seems to be a possible strategy. Mt. Kelud is one of the iconic landscape of Kediri Regency for tourism development. The outstanding landscapes and its geological phenomena are the important assets for tourism development. In the recent rapid grow of tourism development in the mountain area, strengthening cultural service of Mt. Kelud is important. Fundamentally, if it is well planned and managed, nature-based tourism will contribute $s$ to the restoration programs.

A strategy for the strengthening of cultural services of Mt. Kelud though the development of nature-based tourism in $\mathrm{Mt}$. Kelud is important. Based of the field data and secondary data analysis, the strategy for the development of Mt. Kelud can be summarized below (Table 1).

\section{CONCLUSION}

Two ecosystem services were identified in Mt. Kelud, including provisioning and cultural services. Strengthening the value of such ecosystem service will significantly contribute to the success of restoration program, The development of nature-based tourism as one of the cultural services of the restored area is important with some ecological principles to enhance the sustainable tourism development. As many communities in the rural area in developing countries, local community development is crucial.

\section{REFERENCES}

[1].Pratomo, I. 2006. Klasifikasi gunung api aktif Indonesia, studi kasus dari beberapa letusan gunung api dalam sejarah. Indonesian Journal on Geoscience. 1(4):209-227.

[2].Whitten, Tony, R.E Soeriaatmadja, S.A Afiff. 1996. Ecology of Java \& Bali. Vol.2. Oxford University Press.

[3].Zaennudin, A. 2010. The characteristic of eruption of Indonesian active volcanoes in the last four decades. Jurnal Lingkunga ndan Bencana Geologi. 1(2):113-129.

[4].Gunawan, H., Subiandono. 2014. Desain Ruang Restorasi Ekosistem Terdegradasi Di Taman Nasional Gunung Ciremai, Jawa Barat.
Indonesian Forest Rehabilitation Journal. 2(1): 67-78.

[5].Hani, A., Rachman, E. 2007. Tingkat Keberhasilan Model Restorasi di Pondok Injuk Kawasan Taman Nasional Gunung HalimunSalak: Studi Kasus Kampung Cimapag, sebagai Model Kampung Konservasi. Jurnal Penelitian Hutan dan Konservasi Alam. 4(6):591-602.

[6].MA (Millennium Ecosystem Assessment). 2005. Ecosystems and human well-being: synthesis report. Washington DC: Island Press.

[7].Wunder S., Thorsen B.J. 2014. Ecosystem services and their quantification: What are ecosystem services? In: Thorsen B.J., Mavsar R., Tyrväinen L., Prokofieva I., Stenger A.(eds): The Provision of Forest Ecosystem Services: Quantifying and Valuing Non-marketed Ecosystem Services. Joensuu, European Forest Institute: 17-20.

[8].Wirjodarmodjo, H., Bratamihardja, M., Perhutani, P. 1984. Policies Strategies and Design of Forest Development on the Island of Java. Strategies and designs for afforestation, reforestation and tree planting. 363.

[9].Hakim, L., Miyakawa, H. 2013. Plant trees species for restoration program in Ranupani, Bromo Tengger Semeru National Park Indonesia. Biodiversity Journal. 4(3):387-394.

[10].van Steenis, C. G. G. J., Hamzah, A., Toha, M. 1972. Mountain flora of Java. Leiden: Brill.

[11].Miller, J. R., Hobbs, R. J. 2002. Conservation where people live and work. Conservation biology. 16(2):330-337.

[12].Sunderlin, W. D., Angelsen, A., Belcher, B., Burgers, P., Nasi, R., Santoso, L., Wunder, S. 2005. Livelihoods, forests, and conservation in developing countries: an overview. World development. 33(9):1383-1402.

[13].Adhikari, B., Williams, F., Lovett, J. C. 2007. Local benefits from community forests in the middle hills of Nepal. Forest policy and economics. 9(5):464-478.

[14].Djajanti, D., Perhutani, P. 2006. Managing forest with community (PHBM) in Central Java: Promoting equity in access to NTFPs. Hanging in the balance: Equity in communitybased natural resource management in Asia. 63-82.

[15].Zain, M. R. N., Soeaidy, S., Mindarti, L. I. 2011. Kemitraan antara KPH Perhutani dan LMDH dalam menjaga kelestarian hutan. Jurnal Administrasi Publik. 2(2):210-216. 
[16].Winata, A., Yuliana, E. 2015. Potensi tegakan sebagai indicator tingkat keberhasilan pengelolaan hutan bersama masyarakat (PHBM) Perhutani. Jurnal Matematika, Sains, Dan Teknologi. 15(2):106-118.

[17].Mitsch, W. J., Jørgensen, S. E. 2004. Ecological engineering and ecosystem restoration. John Wiley \& Sons.

[18].Rahmawati, S., WidyariniWirjono, S. E. 2014. Dampak Erupsi terhadap Industri Pariwisata di Kawasan Wisata Gunung Kelud Kabupaten Kediri. Electronic Theses\&Dissertations (ETD). Universitas Gadjah Mada. Theses.

[19].Huda, A. M., Bajari, A., Muhtadi, A. S., Rahmat, D. 2017. Functions and Values of Ritual "Larung Sesaji Kelud" in the local Community of Mount Kelud. MediaTor (Jurnal Komunikasi). 10(2):156-164. 